\section{UDC 622.26}

V.F. Dyomin, Dr. Sc. (Tech.), Prof., orcid.org/0000-0002-1718-856X,

A. T. Batyrkhanova, orcid.org/0000-0001-9976-9028,

A. N. Tomilov, orcid.org/0000-0001-6236-9231,

A. Ye. Zhumabekova, orcid.org/0000-0002-1501-5382,

U. E. Abekov, orcid.org/0000-0001-6686-4926
DOI: $10.29202 /$ nvngu/2019-3/2

Karaganda State Technical University, Karaganda, the Republic of Kazakhstan, e-mail: vladfdemin@mail.ru

\title{
DEVELOPING TECHNOLOGICAL SCHEMES OF DRIVING WORKINGS WITH CONTROLLED RESISTANCE OF CONTOURS
}

Mine workings represent a technological hazard in the absence of devices for their safe development.

Purpose. Reinforcement of the contours of mine workings as a safety measure of developing mine workings.

Methodology. The study algorithm is represented in the sequence of stages considering the depth of the excavation, the orientation of the excavation relative to the coal seam, the structure of the coal-bearing layer, the mechanical characteristics of the enclosing array in the preliminary and limit state of typical cross section of the development, the construction and technological characteristics of the supports.

Findings. The study offers data that indicate that if the development area belongs to a flooding area, then the reinstallation of finger bars can be less effective by more than $40 \%$. Field studies have shown that when the secondlevel roof bolting is installed in workings, which are used repeatedly, then they are most likely to have deformed parts in the roof and sides.

Originality. For the first time mathematical models for determining the stability of mine workings are used, as well as models that allow extending the contours of mine workings safely. The requirements for materials that allow carrying out reinforcement of contours considering the structure and technological scheme of the applied technology were determined. This article presents a mathematical model, the approbation and verification of the data obtained at the experimental location. Observations were made regarding the state of workings anchored by roof bolting in the vicinity of geological faults in the zone of influence of high rock pressure of Kostenko, Saranskaia, and Abaiskaia Mines of JSC “Arcelor Mittal Temirtau”. Effects of primary stresses on opening strength are determined.

Practical value. The acquired technology can be used in a controlled environment for the development of mine workings, which have signs of residual capacity and can be developed at better rates and volumes. Testing the method of automated calculation of anchoring parameters and the implementation of research results can improve the technological schemes of the working. Consistencies in calculating the stability of mine workings from the parameters of anchoring was achieved.

Keywords: mining, production contours, flow chart, mathematical model, mounting, mine workings

Introduction. Mine workings have always been the object of technological origin, which were characterized not only by increased hazard, but also formed additional difficulties for the planning of land recultivation after the development. Mine workings differ in a number of problems besides the development itself. In the article we will talk about the safety of mine workings, namely the possibility of reinforcement of their individual elements [1]. In particular, modern mining workings use a phase development mechanism, so that the mining environment is developed in several stages. In addition to the need to strengthen the already-existing mine workings, there is a need to maintain previously completed ones, which, in turn, form the basis of the whole mine workings. If it is necessary for replacement, the process of mining can stop for an extended time, which influences economic and technological costs. In this regard, the technology of phased development and phased

(C) Dyomin V.F., Batyrkhanova A.T., Tomilov A.N., Zhumabekova A. Ye., Abekov U. E., 2019 strengthening of contours with multi-level strengthening will be applied.

The roof can, under certain conditions, form and stop the processes of deformation. The main depth at which the process of formation of a crack begins is up to $700 \mathrm{~m}$. The time interval is from 20 minutes to 3 hours. The depth of cracks can be realized to a depth of 2 meters with the observation period up to 150 meters.

There are still disputes that such cracks can reach the parameters at intervals up to 20-25 meters after each support. Cracks, however, are not a cyclical phenomenon, which cannot always be realized only by installing supporting structures. An increase in the possibility of structuring each individual entity is also required, which is achieved by constantly increasing the flow to the expansion of deformation.

If the depth of production is $800-1000 \mathrm{~m}$, then the process of appearing of cracks in the roof is shifted into the array at $0.5-0.6 \mathrm{~m}$ with a production depth of $500-700 \mathrm{~m}$. The Limit values for cracking are 1.7-2.1 m. The beginnings of cracks in the roof of the excavation 
start at a distance of $2.5-3.5 \mathrm{~m}$. The formation of cracks mainly depends on the nature of the environment in the roof and sides. In particular, proportional dependency is typical. At the same time, a hyperbolic bond is observed in the soil. With the increase in depth of the development to $1000 \mathrm{~m}$, the rate of formation of cracks grows by 1.5-2 times. Conditional areas of inelastic deformations can be found at a distance of $1.6-2.0 \mathrm{~m}$.

A mountain range can be defined as a complex environment, which is formed on the basis of a combination of various geological factors. Within considerable limits, the properties of rocks, which are often referred to and considered as mechanical, can also be formed in their structure. The state of the rocks under consideration is also influenced by the way the process of conducting the work is formed, which is also determined by its unique geological characteristics.

Therefore, it is rather difficult to take into account the diversity of rock array properties, various mechanical models are being studied [2]. Models mostly contain only the essential properties of rocks. Other factors are not comprised in the calculation and are often ignored. The set of core factors includes the strength characteristics and deformation indicators, which include elasticity, plasticity and brittleness. Homogeneity and isotropy are also being studied [3].

Anchor lining strengthens the individual state parameters during mining operations. We believe that the use of such fasteners will be based on what is defined as the value of the metal [4]. That is, it is of primary importance which metal or individual forms this lining consists of. This makes it possible to identify the weak points of the projected lining and present a model that can broaden the understanding of which load lining from another metal can be carried. This also includes the possibility of the formation of a structure that seems to be an enhanced lining option. This set of factors should be defined and expanded.

Unsolved aspects of the problem. Some of the factors that affect the work of the lining are a natural group of reasons. We distinguish the following factors as such:

- technical characteristics of anchor lining;

- geomechanical conditions of the mining operation.

The main task that manufacturers and installers of anchor lining are facing is increased resistance to the appearance and occurrence of cracks.

The main factors affecting the work of anchor lining can be arranged in the following way: mining and geological environments; technical characteristics of anchor lining; geomechanical environment of mining operation.

Development conditions of a geological nature include not only the properties inherent in rocks, such as the properties of a physicomechanical nature, but also the desire to increase the number of cracks in its structure [5].

Technical characteristics of anchor lining include pole material; filler; completeness of filling.

Geomechanical conditions for the conduct and operation of digging are depth; the relative location of the area of influence of refining works; location relative to the waste area [6].
The most difficult issue is to take into account the last group of factors affecting the stability of mine operations.

Depending on mining-and-geological and geomechanical conditions in work, the following support calculations are considered: used in connection with the operations and the one which is also supported outside for protection and refining areas (V1); for the purpose of maintaining support in the area of pressure in the sections of the main workings and interfaces, where the width of the blocks is more than $0.05 \mathrm{H}$, but not less than $15 \mathrm{~m}$ (V2); for operations of the excavation type that are performed by lava (V3); for workings of the excavation type that are protected in the adjacent lava with a minimum width of $15 \mathrm{~m}$ (V4); for workings of the excavation type that are fully protected and kept by adjacent lava, while they should have thickness 2.5-3.0 (V5) of protection layer; workings carried out in the accessory extension to the developed space (V6); mounting chambers (V7).

If we define the parametric aspects of anchoring linings, then the choice of conditions under which the pressure of rocks appears is the intensities that can be determined according to the [7]:

- rock pressure remains low if the rock containment does not reach $50 \mathrm{~mm}$;

- the average intensity of the rock pressure allows being determined already under the condition of achieving displacements of 50-200 mm;

- considerable intensity of the pressure of the mountain type is determined under the condition that the displacements reach the parameters defined as the excess over $200 \mathrm{~mm}$.

If the pressure is of minor importance, in the case of a calculated displacement of less than $50 \mathrm{~mm}$ with resistance anchor support RA and length of anchors La, which are usually installed in the lower hole, they are taken depending on the type of roof. For type II rocks, PA is accepted as for type I, and the length of La anchors can be reduced by $20 \%$. For roofs of types I and III, anchors can be reduced in length by $10-20 \%$ by increasing the density of anchoring or using anchors of increased bearing capacity, and the calculated anchor support resistance should be increased by 30 and $50 \%$, respectively.

Purpose. Mine workings are not only the basis for mining, but also represent a technological hazard in the absence of mechanisms for their safe development. The authors propose to use fortifications of the contours of mine workings as a security measure for the development of mining operations.

Results. Anchor lining, as well as additional means of strengthening should depend on a number of parameters that include the intensity of rock pressure. In turn, it depends on size, depth at which the working is located, as well as the depth of its occurrence. One should take into account the possibility of protecting the workings from the impact of the ongoing refining works, potential cracking, and variance in stability of materials, which form rocks. If the calculated dislocations exceed a predetermined threshold of $300 \mathrm{~mm}$, then their suppres- 
sion is carried out at the boundary with the developed area and the remaining rocks are protected as a separate space [8].

The main indicators regarding the parameters of anchor lining are estimated displacements and expected loads for anchoring. The main parameters of anchor lining are: pole length, $\mathrm{m}$; distance between anchors in a row; distance between rows of anchors. The main parameters of anchor lining depend on the values of the calculated dislocations and loads on the lining. The length of the pole (anchor) depends on the mode of operation of the anchor system. There are two modes of operation of anchor lining: connecting weak rock to hard rock; connecting the weak layers together to create a single beam. Connecting weak rock to more durable overlying rocks, the length of the anchor will be determined by the formula, $\mathrm{m}$

$$
L_{a}=m_{l}+l r+l s,
$$

where $m_{l}$ is the power layers of soft rock, $m ; l r$ is the length of the part of the anchor recessed into hard rocks, $\mathrm{m}$, at least $0.3 \mathrm{~m}$; $l s$ is the length of the part of the anchor serving in the development, m; depending on the design of the anchor (usually not less than $0.1 \mathrm{~m}$ ).

At high power of soft rocks, it is impossible to connect weak layers to stronger ones with short anchors ( $2.4 \mathrm{~m})$, a single support beam is created with $2.4 \mathrm{~m}$ long anchors, then using long anchors ( $3.5 \mathrm{~m}$ long and more) the created beam is connected to hard rocks. In this case, the length of the anchors is taken in such a way that the end of the anchor is recessed into hard rocks for at least $0.5 \mathrm{~m}$.

The space between the anchors in a row is determined based on the specified bearing capacity of the anchor and the expected loads [9], $\mathrm{m}$

$$
A_{a}=(\mathrm{Na} / \mathrm{Pa})^{0.5} \text {. }
$$

Time development of cracking $(R c)$ depending on the depth of location $(H)$ with anchoring at the roof and sides (3), for soil (4), $\mathrm{m}$ is determined

$$
\begin{gathered}
R_{c}=1.03+0.0005 H+0.06 T \\
R_{c}=1.4+0.0005 H+0.1 T
\end{gathered}
$$

The dependency of the depth of crack propagation $\left(R_{c}, \mathrm{~m}\right)$ in the host rocks depending on the formation incidence angle ( $\alpha$, hail) and the controllability of the roof rocks $\left(\frac{H n \cdot k .}{t}\right)$ is determined as

$$
R_{c}=1.1+0.07 \frac{H n . k .}{t} ; \quad R=1.9+0.06 \alpha .
$$

The empirical dependency of the approach magnitude $(C, \mathrm{~m} /$ day $)$ and the deformation intensity $\left(R_{d}, \mathrm{~m}\right)$ of the roof rocks is established

$$
\begin{gathered}
C(l)=-2 \cdot 10^{-3} \cdot L+8.8 \cdot 10^{-3} \\
R(l)=-0.04 \cdot \sqrt[3]{L}+0.25
\end{gathered}
$$

Dislocation of roof rocks $\Delta U_{\mathrm{o}}$ around the preparatory operations in the area of the cleaning works, depend- ing on the period of maintenance $(T)$ for anchor lining, vary according to the empirical dependence

$$
\Delta U_{t}(T)=16.34 T^{0.291} \text {. }
$$

Dependency of rock deformations $(U, \mathrm{~mm})$ in workings in the depth of mining $(H, \mathrm{~m})$ for anchor lining is

$$
U(H)=8.3 H^{0.7} \text {. }
$$

The empirical dependency of the sides dislocations $\left(B_{s}\right)$ of the width of the excavation $\left(W_{e}\right)$ is determined as

$$
B s(b)=0.09 W e^{2}-0.7 W e+2 .
$$

Empirical dependency of the change in the deformation rate $(U, \mathrm{~mm} / \mathrm{day})$ of roof rocks on the bearing capacity of supports $\left(R, \mathrm{t} / \mathrm{m}^{2}\right)$ is

$$
U(R)=0.19 e^{-0.8 R} \text {. }
$$

The influence of rock pressure $(Q, \mathrm{kH})$ during the anchorage of preparatory workings for anchor rods of reinforcing steel, $21.6 \mathrm{~mm}$ at displacements $(N, \mathrm{~m})$ is

$$
Q(U)=46 N^{0.4} \text {. }
$$

When limited to cracking, the shape of the fracture zones is parabolic. Which means that the cross-sectional area, and, consequently, the mass per unit of excavation length is easy to calculate.

The formation of a beam, which will have elasticity within the rock layer, is possible only using an anchor rod, which has a length in the range of 2.0-2.4 $\mathrm{m}$. The second level determines the connection of such an anchor rod with a length of more than $3 \mathrm{~m}$, when the interval in which it is installed, can reach no more than $0.1 H$ from the first lava. This will reduce the number of hydraulic type stands, which are classified as additional and form a retaining mechanism by $80-85 \%$.

By increasing the number of dislocations, the thickness of the roof in the rock decreases in carrying capacity. In the calculations of the parameters of anchor lining, a ratio is used, which is introduced within the limits of increasing the bearing capacity of the lining. Depending on the value, the initial value of the ratio can be $1.1-1.6$, and subsequently this parameter can vary widely.

The study [10] shows how a system can be implemented that allows a two-level anchor to be implemented. Such laying can be pliable, and also depends on the size of the dislocation prisms, which are formed on the sides of the development and depend on the size of the sliding prisms. The establishment of a mechanism that allows deforming the rocks situated in the sides of the workings and determining the parameters that are used when installing anchor lining, is designed using the fit of side thrust and identifying the dependence on the length of the anchor rod

$$
r=R+q-F_{m p}
$$

Side expansion is denoted as $R$ in equation (13). In this expression, the lateral thrust force, the volume of output is determined. 
In equation (13), the side thrust forces, which cause damages in the sides of the workings, are determined by the expression

$$
R=\left(K_{o} \gamma H_{c}\right) \cdot \lambda h_{B},
$$

where $K_{o}$ is the concentration ratio of the reference pressure; $\gamma$ is the average volume weight of the array; $H$ is deposition of the development from the surface; $\lambda$ is the ratio of side thrust; $h_{B}$ is the height of production.

The forces that carry out the friction $N_{m p}$ are calculated additionally. They prevent the spin in the development in the sides and reduce the likelihood of destruction, which is determined by the expression

$$
N_{m p}=r\left[\exp \left(\frac{2 n_{m p} \cdot l_{p}}{\lambda \cdot m_{B}}\right)-1\right]
$$

where $r$ is the resistance of lining to extraction; $n_{m p}$ is the ratio of friction of the rocks of the roof and soil; $l_{p}$ is the depth of the area of damaged rocks in the sides of the workings; $m_{B}$ is power of destructible rocks in the sides of the workings.

The maximum value of the force of pressure in rocks in the production $q$ is determined by the expression

$$
q=\gamma_{y} l_{p} h_{B} \lambda,
$$

where $\gamma_{y}$ is the volumetric weight of damaged rocks in the sides of the workings.

After the final transformations, the required resistance of the anchor lining in the sides of development can be calculated by the formula

$$
r=\frac{\left[\left(K_{o} \gamma H-\sigma_{c}\right) \cdot \lambda+\gamma_{y} l_{p} \lambda\right] h_{B}}{\exp \left(\frac{2 n_{m p} l_{p}}{\lambda \cdot m_{B}}\right)} .
$$

The depth of the fracture area is calculated by the formula

$$
l_{p \max }=\frac{\left\{\lg \left[\left(K_{o} \gamma H-\sigma_{c}\right) \cdot \lambda+r\right]-\lg r\right\} \cdot \lambda \cdot h_{B}}{2 n_{m p} \lg e} .
$$

Analysis of the results allows us to conclude that it is impossible to eliminate the damage of side rocks. The depth of anchoring of the sides of the workings is comprised in the range of $2-2.5$ meters or more

$$
H_{d . s .}>\frac{R_{c s}}{K_{o} 2 \gamma},
$$

where $R_{c s}$ is the strength of rocks for uniaxial compression of side rocks.

The depth that we denote as separation from the height $H_{d . s}$ at certain values of the width of destruction, is 2.5 times greater than the magnitude of the prism. At the same time, the depth exceeds the average values by 1.5-2 times compared to the height of $H_{d . s}$.

Fig. 1 shows the currently used (a) and proposed by the mine (b) construction of a deep-laid anchor.

Experimental-industrial installation of construction anchors was performed at Karaganda State Technical University in the period from 01.06 .18 . to 29.06 .18 , ex-

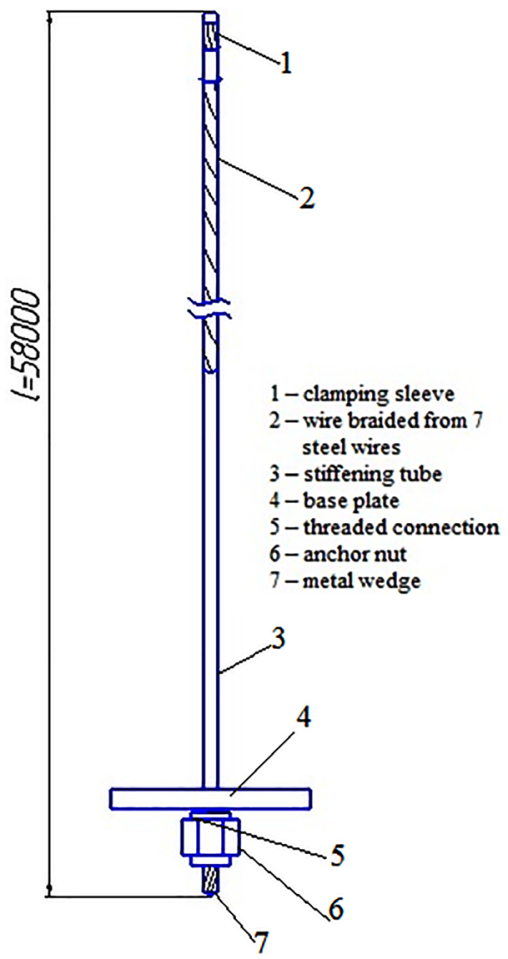

$a$

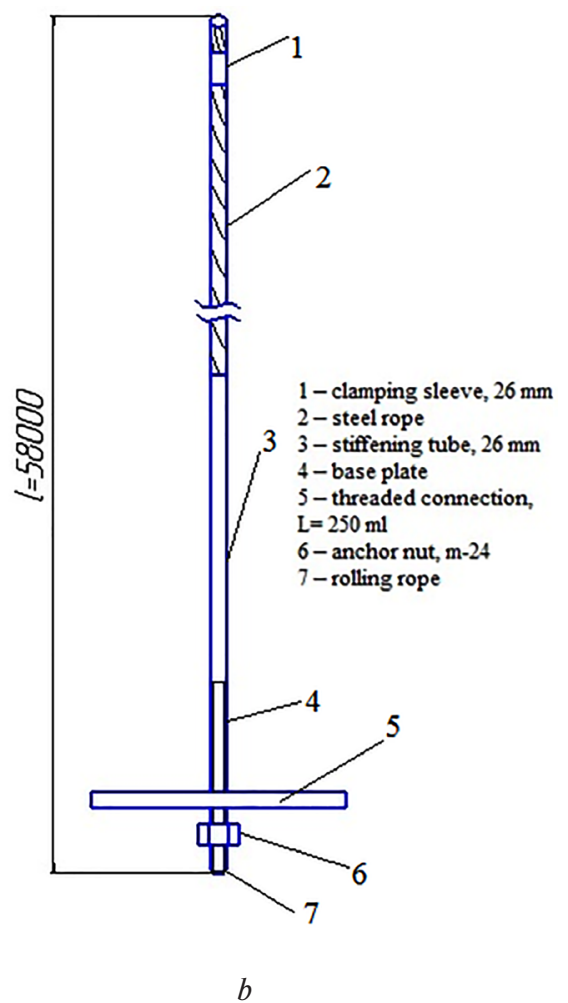

b

Fig. 1. Construction of a deep-laid anchor made (a) and proposed by the mine (b) 
perimental cable anchors at Kostenko mine, Coal Department of JSC "Arcelor Mittal Temirtau”.

As a result of experimental-industrial procedure of installed experimental cable anchors produced by Karaganda State Technical University with the conveyor incline of $44 \mathrm{bk}_{10^{-3}}$ and the ventilation drift $49 \mathrm{~K}_{7}-3$, an experimental batch of cable anchors was tested in the quantity of 50 pieces [11].

As a device, a matrix and a punch were used. The press compression was $630 \mathrm{~kg} / \mathrm{cm}^{2}$. With the help of the grinder the excess ends of the wire were cut off.

After conducting industrial tests of prototype anchor at Kostenko mine, JSC "ArcelorMittal Temirtau", a number of observations were made (Fig. 2): the anchors should be rigidly connected to each other in all parts; the clamping clutch should have an external diameter of $26 \mathrm{~mm}$, since hole diameter is $228 \mathrm{~mm}$; stiffening tube should have an external diameter of $26 \mathrm{~mm}$ and a length of $1200 \mathrm{~mm}$; the inlet opening on the support plate should have a diameter equal to the outer diameter of the stiffening tube; it is desirable that the threaded connection for the anchor nut should be on the stiffening tube, which, in turn, should be rigidly connected to the cable at the outlet; it is also desirable that the threaded connection should have a diameter fitting the standard M24 nut and a thread length of at least $250 \mathrm{~mm}$ for installing the anchor using the Super Turbo Bolter installation with a standard adapter.

The comments were taken into account, the design adjustment has been made and the subsequent anchors will be performed according to the comments. According to the comments, the thread length should be 250 $\mathrm{mm}$ with an M-36 nut, since the M-24 nut is technologically impossible to make: when reducing the diameter of the sleeve, it is weakened and deformed when the nut is screwed in - Fig. 2.

The technical result with improvements in performance is achieved by eliminating the processes of dislocation and stratification of rocks that fit snugly to the

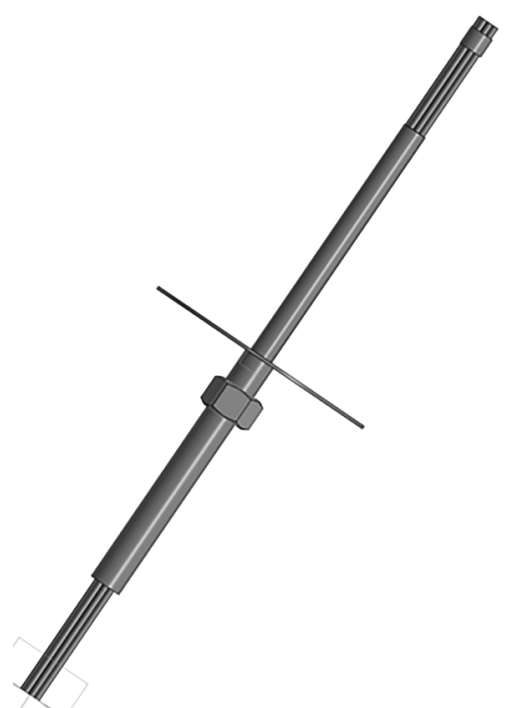

Fig. 2. The design of the anchor AKMK 1, made at "Karaganda Machine-Building Consortium” LLP attachment points. In the developed part, a flat beam is used, which is fixed at an angle to the stratification. Fig. 3 shows how to apply the mounting scheme. This process is more preferable, as it uses a technologically more advanced process and reduces the cost of operation and repair. Fig. 4 shows a rope anchor with chemical ampoules of different attachment techniques, which allow creating pre-tension of the rope and increasing the carrying capacity of the anchor.

Conclusion. The completed studies have shown that if there is a large displacement in the rocks, especially in the pressure zone of the first lava, there is a need to install frame supports. At the same time, the installation should be done during periods when the development is

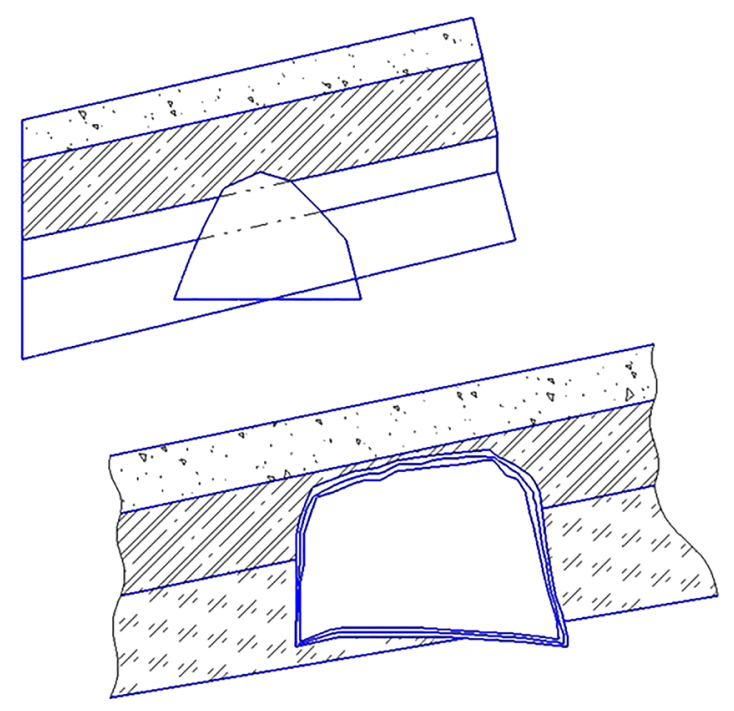

Fig. 3. The method of mounting mining production in the zone of violation on a thin layer
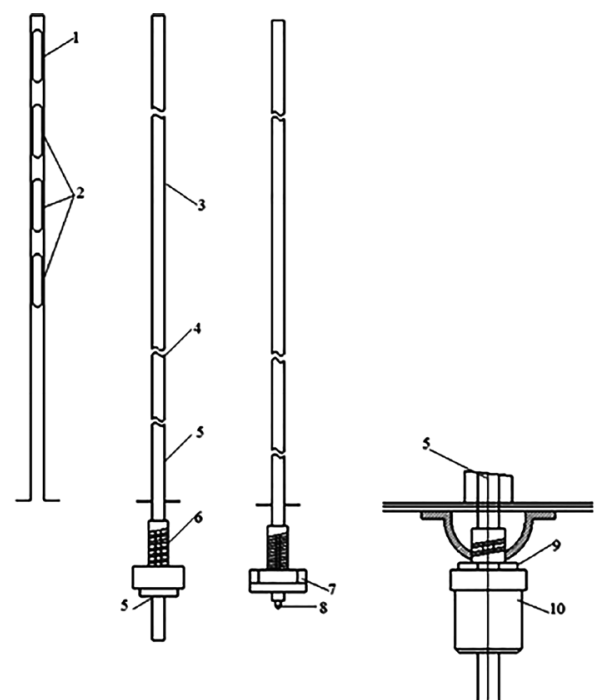

Fig. 4. Scheme of construction of a cable anchor with chemical ampoules of different fixing timing:

1 - chemical ampoule with fixing synthetic solution; 2 mineral ampoule; 3 - carrying cord; 4 - air discharge tube; 5 - sealer; 6 - bearing sleeve; 7 - discharge nut; 8 - ring; 9 - nut; 10 - fitting 
just beginning to advance in a new section, and for cases when there was a pull-out of locks, as well as breaks in the rods.

Combinations of reinforcement supports are usually mounted in the area of influence of cleaning work. If the anchor lining of an additional type has a rod length of more than 3 meters, then there is no need for additional work. And the volume of workings can also be extremely insignificant. If the production is carried out outside the area of influence of the cleaning work, then the parameters of the anchor chain can be determined for dislocations up to $50 \mathrm{~mm}$. According to the results of the study, it was also found that after a period of 50-70 days, the displacement value reaches values of $65-90 \mathrm{~mm}$. The inelastic type deformation zone in the roof rocks can reach 3-4 m, which already establishes completely different requirements for anchor chains. A significant quantity of mine measurements and research studies were conducted; however, the mechanism by which the interaction between the deformed host rocks and anchor chains is regulated is still very little studied.

If the workings are used again, there should be an additional fixing element. We have identified two acceptable options as the result of the study.

At displacements of more than $200 \mathrm{~m}$, lining with reinforcement can be used, which should be installed under the holders. This rack gain increases the carrying aptitude. They also keep stratified rocks under definite conditions. This is feasible, provided that it is accompanied with reinforcement racks. The attained recommendations were fully confirmed in the course of field experiments.

Beyond the first contour, anchor chains with a rod length in the range of $2.0-2.3 \mathrm{~m}$ can be used. This ensures the formation of rock stratified beams, which have a high elasticity. The second level should be set at a distance of 0.1 from the first contour. This reduces the quantity of used hydraulic racks by $80 \%$.

\section{References.}

1. Mamet'ev, Yu. I., Ibraev, D.S., Krupnik, L.A., \& Shaposhnik, Yu. N. (2014). Technological Innovation in Long Raise Boring and Construction. Gorny Zh. Kazakh., 7, 5-9.

2. Galvin, J. M. (2016). Pillar Extraction. In Ground Engineering - Principles and Practices for Underground Coal Mining (pp. 309-358). Cham: Springer International Publishing. DOI: 10.1007/978-3-319-25005-2_8.

3. Bogomolov, A. N., Bogomolova, O.A., \& Ushakov, A. N. (2018). About Stresses in a Contour Points in a Single Underground Mines of Different Cross Sections, Subject to an Overall Uniform Pressure. Bulletin of PNRPU. Construction and Architecture, 9(3), 54-70. DOI: 10.15593/2224-9826/2018.3.06.

4. Baryshnikov, V.D., Baryshnikov, D. V., Gakhova, L. N., \& Kachal'sky, V. G. (2014). Practical Experience of Geomechanical Monitoring in Underground Mineral Mining. J Min Sci, 50(5), 855-864. DOI: 10.1134/S1062739114050056.

5. Kurlenya, M.V., Baryshnikov, V.D., \& Gakhova, L. N. (2013). Effect of Partial Water Flooding on the
Stress-Strain State of the Crown Pillar in the Aikhal Mine. J. Min. Sci., 49(4), 537-543. DOI: 10.1134/ S1062739149040023.

6. Bogomolov, A.N., Bogomolova, O.A., \& Ushakov, A. N. (2017). Determination of the Laying Depth of Horizontal Mine Workings by Stress State Analysis of Enclosing Soil Mass. Soil Mechanics and Foundation Engineering, 54(5), 295-302. DOI: 10.1007/s11204-0179472-2.

7. Krupnik, L.A., Shaposhnik, Y. N., Shokarev, D.A., Shaposhnik, S. N., \& Konurin, A. I. (2017). Improvement of Support Technology in Artemevsk Mine of Vostoktsvetmet. Journal of Mining Science, 53(6), 10961102. DOI: 10.1134/S1062739117063173.

8. Bustillo Revuelta, M. (2018). Mineral Resource Extraction. In Mineral Resources: From Exploration to Sustainability Assessment (pp. 311-421). Cham: Springer International Publishing. DOI: 10.1007/978-3-31958760-8_5.

9. Kurlenya, M.V., Baryshnikov, V.D., \& Gakhova, L. N. (2013). Effect of Partial Water Flooding on the Stress-Strain State of the Crown Pillar in the Aikhal Mine. J. Min. Sci., 49(4), 537-543. DOI: 10.1134/ S1062739149060166.

10. Schumacher, F. P., \& Kim, E. (2014). Evaluation of Directional Drilling Implication of Double Layered Pipe Umbrella System for the Coal Mine Roof Support with Composite Material and Beam Element Methods Using FLAC 3D. Journal of Mining Science, 50(2), 335348. DOI: 10.1134/S1062739114020173.

11. Zhang, Y., Kang, Z., \& Hou, C. (2010). Research on Numerical Analysis of Landslide Cataclysm Mechanism and Reinforcement Treatment Scheme in ShengLi Open-Pit Coal Mine. In R. Zhu, Y. Zhang, B. Liu, \& C. Liu (Eds.), Information Computing and Applications (pp. 565-572). Berlin, Heidelberg: Springer Berlin Heidelberg. DOI: 10.1007/978-3-642-16336-4_11.

\section{Розробка технологічних схем проведення гірничих виробок з управлінням стійкістю контурів при багаторівневому кріпленні}

\author{
В. Ф. Дьомін, А. Т. Батирханова, О. М. Томілов, \\ А. Є. Жумабекова, У. С.Абеков
}

Карагандинський державний технічний університет, м. Караганда, Республіка Казахстан. e-mail: vladfdemin@ mail.ru

Гірничі виробки становлять технологічну небезпеку за відсутності механізмів їх безпечної розробки.

Мета. Укріплення контурів гірничих виробок як захід безпеки розробки гірничої виробки.

Методика. Алгоритм досліджень відображено у вигляді послідовності виконання етапів з урахуванням глибини розташування виробки, орієнтування виробки щодо вугільного пласта, структури вуглевмісної товщі, механічних характеристик масиву, що вміщає виробку, у до граничному та граничному стані, типового перерізу виробки, конструктивно-технологічних характеристик кріплення. 
Результати. У роботі наведено дані, які свідчать про те, що якщо використовується зона робіт, яка належить до зони підтоплення, то установка підпірних стійок повторно може бути менш ефективною на 40 \% і більше. Виявлено, що випадок для шахтної установки зводиться до вирішення геомеханічної аналітичної задачі. Натурні дослідження показали, що, якщо анкерне кріплення другого рівня встановлюється у виробках, що використовуються повторно, то ймовірно вони в покрівлі й боках мають породи деформованого вигляду.

Наукова новизна. Уперше застосовані математичні моделі визначення стійкості гірничих виробок і моделі, що дозволяють безпечно розширювати контури гірничих виробок. Визначені вимоги до матеріалів, що дозволяють проводити зміцнення контурів з урахуванням структури й технологічної схеми застосовуваної технології. У роботі представлена математична модель, iї апробація та верифікація отриманих даних на дослідній ділянці. Проведене спостереження за станом виробок, закріплених анкерним кріпленням, пройдених поблизу геологічних порушень у зоні впливу підвищеного гірського тиску шахт „Ім. Костенко“, „Саранська“, „Абайська“ УД АТ „АрселорМіттал Теміртау“. Установлено вплив головних напружень на стійкість гірничих виробок.

Практична значимість. Отримана технологія може використовуватися в контрольованому середовищі для розробок гірничих виробок, що мають ознаки залишкової ємності й можуть бути вироблені у глибших нормах і обсягах. Для цього необхідно проаналізувати перспективні форми виробки і позначити географічно райони, що можна використати із застосуванням розробленої технології. Проведена апробація методики автоматизованого розрахунку параметрів анкерного кріплення й реалізація результатів досліджень щодо вдосконалення технологічних схем проведення виробок. Виявлені закономірності для розрахунку стійкості гірничих виробок від параметрів анкерного кріплення.

Ключові слова: гірнича справа, контури вироблення, технологічна схема, математична модель, кріплення, гірничі виробки

\section{Разработка технологических схем проведения горных выработок с управлением устойчивостью контуров при многоуровневом креплении}

\section{В. Ф. Демин, А. Т. Батырханова, А. Н. Томилов, А. Е. Жумабекова, У. Е. Абеков}

Карагандинский государственный технический университет, г. Караганда, Республика Казахстан. е-mail: vladfdemin@mail.ru

Горные выработки представляют собой технологическую опасность при отсутствии механизмов их безопасной разработки.
Цель. Укрепление контуров горных выработок в качестве меры безопасности разработки горной выработки.

Методика. Алгоритм исследований отражен в виде последовательности выполнения этапов с учетом глубины расположения выработки, ориентировки выработки относительно угольного пласта, структуры углевмещающей толщи, механических характеристик вмещающего выработку массива в допредельном и предельном состоянии типового сечения выработки, конструктивно-технологических характеристик крепи.

Результаты. В работе приведены данные, которые свидетельствуют о том, что если используется зона работ, относящаяся к зоне подтопления, то установка подпорных стоек повторно может быть менее эффективна на 40 \% и более. Выявлено, что случай для шахтной установки сводится к решению геомеханической аналитической задачи. Натурные исследования показали, что, если анкерная крепь второго уровня устанавливается в выработках, которые используются повторно, то скорее всего они в кровле и боках имеют породы деформированного вида.

Научная новизна. Впервые применены математические модели определения устойчивости горных выработок и модели, которые позволяют безопасно расширять контуры горных выработок. Определены требования к материалам, которые позволяют проводить укрепление контуров с учетом структуры и технологической схемы применяемой технологии. В статье представлена математическая модель, ее апробация и верификация полученных данных на опытном участке. Проведено наблюдение за состоянием выработок, закрепленных анкерной крепью, пройденных вблизи геологических нарушений в зоне влияния повышенного горного давления шахт „Им. Костенко“, „Саранская“, „Абайская“ УД АО „АрселорМиттал Темиртау“. Установлено влияние главных напряжений на устойчивость горных выработок.

Практическая значимость. Полученная технология может быть использована в контролируемой среде для разработок горных выработок, которые имеют признаки остаточной емкости и могут быть выработаны в более глубоких нормах и объемах. Для этого необходимо проанализировать перспективные формы выработки и обозначить географически районы, которые могут быть использованы с применением разработанной технологии. Произведена апробация методики автоматизированного расчета параметров анкерного крепления и реализация результатов исследований по совершенствованию технологических схем проведения выработок. Выявлены закономерности для расчета устойчивости горных выработок от параметров анкерного крепления.

Ключевые слова: горное дело, контуры выработ$\kappa и$, технологическая схема, математическая модель, крепление, горные выработки

Рекомендовано до публікації докт. геол. наук М.Р.Шаутеновим. Дата надходження рукопису 14.01.18. 